\title{
Comparing two concepts of the OECD-NEA RK\&M Initiative (2011-2019): The Set of Essential Records and the Key Information File
}

\author{
Stephan Hotzel \\ Federal Office for the Safety of Nuclear Waste Management (BASE), \\ Wegelystrasse 8, 10623 Berlin, Germany \\ Correspondence: Stephan Hotzel (stephan.hotzel@bfe.bund.de) \\ Published: 10 November 2021
}

\begin{abstract}
In the last decade, the Nuclear Energy Agency (NEA) of the OECD co-ordinated an international initiative to develop understanding and guidelines related to the longer-term preservation of records, knowledge and memory (RK\&M) regarding radioactive waste repositories, the so-called "RK\&M Initiative". Their final report (NEA, 2019) can be read as a general guide to the RK\&M preservation topic. In terms of practical support, the group prepared an RK\&M preservation toolbox, comprising 35 different preservation mechanisms. Amongst those are classical, much discussed tools such as "archives", "surface markers" or "land use control", hitherto less discussed tools such as "international regulations", "small time capsules" or "clear and planned responsibilities", and two entirely new concepts: the Set of Essential Records (SER) and the Key Information File (KIF).

In the current contribution, I present these two concepts, pointing out their role both in the wider RK\&M preservation context (i.e. in the toolbox as a whole) and in the narrower "documents" context. My main focus is a comparative approach, addressing the peculiarities of the KIF and the SER concepts by working out the differences between the two. It becomes apparent that the KIF is far from being a condensation of the SER, but in fact KIF and SER are independent concepts: in terms of their authors/creators, their target audiences, and first and foremost their functioning, i.e. "how" they contribute to RK\&M preservation.
\end{abstract}

Kurzfassung. Im letzten Jahrzehnt hat die Kernenergie-Agentur Nuclear Energy Agency (NEA) der OECD eine internationale Initiative koordiniert, die sogenannte RK\&M-Initiative, um Einsichten und Richtlinien für den längerfristigen Erhalt von Aufzeichnungen, Wissen und Erinnerung (records, knowledge and memory, RK\&M) zu Endlagern für radioaktiven Abfall zu entwickeln. Ihr Abschlussbericht (NEA, 2019) lässt sich als allgemeiner Leitfaden für das Thema RK\&M-Erhalt lesen. Zur praktischen Unterstützung hat die Gruppe eine Toolbox für den RK\&M-Erhalt erstellt, die 35 verschiedene Mechanismen für den Erhalt umfasst. Darunter befinden sich klassische, viel debattierte Instrumente wie Archive, Oberflächenmarkierungen oder die Steuerung der Landnutzung, bisher weniger diskutierte Instrumente wie internationale Bestimmungen, kleine Zeitkapseln oder eindeutige und geplante Zuständigkeiten sowie zwei vollkommen neue Konzepte: die Zusammenstellung von unerlässlichen Unterlagen (Set of Essential Records, SER) und von Schlüsselinformationen (Key Information File, KIF).

In diesem Beitrag stelle ich diese beiden Konzepte und ihre Funktion sowohl im weiteren Kontext des RK\&MErhalts (d.h. der gesamten Toolbox) als auch im engeren Kontext der Dokumente vor. Mein Hauptaugenmerk liegt auf einem vergleichenden Ansatz, der die Besonderheiten der KIF- und SER-Konzepte aufgreift und die Unterschiede zwischen beiden herausarbeitet. Es wird deutlich, dass es sich beim KIF bei weitem nicht um eine Zusammenverfassung des SER handelt, sondern KIF und SER unabhängige Konzepte darstellen. Dies gilt in Bezug auf ihre Ersteller, ihr Zielpublikum und vor allem ihre Funktionsweise, d.h. die Art und Weise, wie sie zum RK\&M-Erhalt beitragen. 


\section{References}

Nuclear Energy Agency (NEA): Preservation of Records, Knowledge and Memory (RK\&M) Across Generations - Final Report of the RK\&M Initiative, NEA no. 7421, OECD, available at: https://www.oecd-nea.org/upload/docs/application/pdf/ 2019-12/7421-rkm-final.pdf (last access: 3 November 2021), 2019. 